\title{
The Authority of the Sunnah According to the Qur'anic Text
}

\author{
Ahmad Eldridge Cleaver
}

\begin{abstract}
This study analyzes what the Qur'an ascribes to the Sunnah of Muhammad and highlights the existence of indicators within the Qur'anic text as to the Sunnah's significance, role, and legal authority. Insight into its place and role is researched according to the Qur'an, and answers are sought as to its significance in Islamic law and thought. The answers presented are the ones found in the Qur'anic discourse circulating around Muhammad. The analysis, which examines thirty-five Qur'anic verses that mention Muhammad, is organized according to several themes, among them obedience to God and to Muhammad and the latter's judicial role.
\end{abstract}

\section{Introduction}

The Qur'an, the first source of the Islamic lifestyle, ${ }^{1}$ contains numerous rules and broad guidelines related to religious, spiritual, moral, legal, social, and economic matters, as well as to what is acceptable in war and peace. ${ }^{2}$ Such verses are often constructed as a direct dialogue with Muhammad (Q. 2:80, 97, 135; 3:154; 8:38; 17:110). For example, Q. 2:80 proclaims:

\footnotetext{
Ahmad Eldridge Cleaver is an American Ph.D. candidate in Islamic studies at the International University of Africa in Khartoum, Sudan. He earned his M.A. in Islamic studies from the Centre of Islamic Studies, School of Oriental \& African Studies, University of London. His first published book Soul on Islam (Seaburn: 2006) is a partly biographical work that discusses misconceptions about Islam and his conversion. Cleaver lectures on Islam in universities, libraries, and bookstores, as well as in Makka to Hajj pilgrims. He is professionally affiliated with the National Institute of Technology in Jeddah, Saudi Arabia as an English language instructor.
} 
They say: "The Fire will only touch us for a few days." Say to them: "Have you received a promise from God - for God never breaks His promise - or are you saying things about Him of which you have no real knowledge?" (Q. 2:80)

In addition, the Qur'an gives indications of Islam's sources of authority. This study asks: What can be inferred about the Sunnah from the Qur'an? Does it attribute any significant importance to the Sunnah? How does it describe Muhammad's role? Does it attribute any authority to the Sunnah? Answers to these questions will be sought by means of a critical analysis of the Qur'anic text.

In linguistic terms, sunnah originally meant "a way of conduct, an act or custom, a well-beaten path, an established consistent practice, and a manner or a methodology for doing something" (Q. 17:77, 35:43). ${ }^{3}$ This particular term, which appears sixteen times in the Qur'an, always carries this meaning. ${ }^{4}$ For example: "Such was Our way (sunnah) with the Messengers We sent before you, and you will find no change in Our ways" (Q. 17:77) and

They became more arrogant in the land and intensified their plotting of evil - their plotting of evil only rebounds on those who plot. Do they expect anything but what happened (sunnah) to earlier people? You will never find any change in God's practice (sunnah); you will never find any deviation there. (Q. 35:43)

In the terminology of Islamic studies, however, this term specifically came to mean Muhammad's words, actions, tacit approvals, and his ways and consistent practices. ${ }^{5}$ The term hadith signifies the written documentation by which Muslim scholars stove to preserve the Sunnah during Islam's early centuries. ${ }^{6}$

\section{Methodology}

I subject thirty-five significant Qur'anic verses to critical analysis to deduce the presence or absence of indicators to the Sunnah so that its place in and relevance to Islam can be examined and defined. The asbāb al-nuz $\bar{l} l$ (the occurrences and reasons for the revelations), Arabic linguistics, hadith and $\bar{a} t h \bar{a} r$ (sayings of the Companions and the Followers) are employed to assess the significance and meanings of the Qur'anic discourse about Muhammad. The verses presented are listed in table 1 . 


\section{Contemporary Discussions}

The majority of contemporary Sunni scholars see Muhammad's sunnah as a source of law next in authority to the Qur'an. ${ }^{7}$ Some contemporary scholars posit that this view is mainly due to the efforts of Muhammad ibn Idris al-Shafi' $i$ (d. 204/820), who actively taught that the Sunnah is a source of authority for Islamic law and a revelation (wahy) second only to the Qur'an. ${ }^{8}$ His Al-Risālah, one of the first written works on the fundamental principles of Islamic jurisprudence ( $u s \underline{u} l$ al-fiqh), was the first to present a sophisticated argument supporting this view. ${ }^{9}$ Some scholars, however, argue that important muhaddithün (hadith scholars) preceded him and taught these concepts. ${ }^{10}$ According to this understanding, al-Shafi ${ }^{\circ} i$ essentially conveyed the teachings of many of his predecessors from the second and third generations of Muslim scholarship. ${ }^{11}$

His argument that obeying the Sunnah is obligatory is very effective, due to his interpretation of hikmah (wisdom), when it appears in a verse with the word Qur'ān, as a synonym for sunnah (Q. 33:34, 62:2). ${ }^{12}$ Al-Shafi'i's work had a profound influence and, it can be said, provided the first sophisticated written articulation that the Sunnah was a form of divine revelation. Although his written treatises on its authority were very detailed and focused, the documentation on his predecessors' discussions is limited and not easy to access. But researching the hadith scholarship of Muhammad ibn Shihab al-Zuhri (d. 124/742), al-A'mash (d. 148/765), Ibn Jurayj (d. 150/767), Shu'ba ibn alHajjaj (d. 160/776) Sufyan al-Thawri (d. 161/778), Malik ibn Anas (d. 179/795), and Sufyan ibn 'Uyayna (d. 196/811) does reveal that al-Shafi'i's view was also expressed by his predecessors. ${ }^{13}$

On the other hand, many Hanafi, Rationalist, and Mu'tazili scholars disagree that Islamic law should be deduced strictly based on the Qur'an and the Sunnah. They make a clear distinction between the authority attributed to a hadìth ahad (only one or two people cited at any stage of the $i s n \bar{a} d$ [chain of narrators]) and a hadìth mutawātir (one narrated by numerous people at each level of the $i s n \bar{a} d$ ). They accept a hadith as a proof for evidence in ahkām (legal rulings) or 'aqidah (tenets of faith, doctrine, and belief) only if it is $m u$ tawātir. ${ }^{14}$ Much of al-Shafi'i's Al-Risālah is set in the form of lengthy debates between him and unnamed opponents who disagree that adherence to the Sunnah is obligatory.

Scott C. Lucas and other scholars describe the other side of this contemporary Muslim discussion as "Classical Salafi Islam" or "Traditionalist Salifis." ${ }^{15}$ The Salafis comprise a minority of scholars who assert that every 
hadith with an authentic isnād and matn (text or words) is an acceptable proof and can therefore be used as evidence for all aspects of Islam, including ahkām or 'aqïdah. ${ }^{16}$ In their assessment, refusing to accept a hadith ahad is tantamount to neglecting a part of the Sunnah. Ibn Taymiyyah, Ahmad ibn Hanbal, and many other hadith scholars observed and propagated this methodology. ${ }^{17}$

\section{The Sunnah in the Qur'an}

To discover how the Qur'an perceives the Sunnah, one must realize that many of its verses are general and thus give guidelines, principles, and directions in the form of broad themes. Thus one does not always find conveyed the exact specifics of how to implement some of its injunctions. For example, the description of salāt (the daily ritual congregational prayer) is incomplete, although the Qur'an mentions it sixty-seven times as an act of worship comprised of standing in prayer (Q. 22:26, 37:165), bowing (Q. 9:112, 39:9), prostrating (Q. 3:111, 9:112, 22:26, 39:9, 48:27), glorifying God (Q. 18:28, 24:58), and submitting to the Creator (Q. 23:2). ${ }^{18}$

Likewise, although the Qur'an states that each prayer must be performed at a fixed time (Q. 4:103), it does not give very precise details: "early dawn" (Q. 17:78) and "at morning" (Q. 33:42), "when the day begins to decline" (Q. 30:18), "in the afternoon" (Q. 33:42), "at the rising and setting of the sun" (Q. 50:39), and "at the two ends of the day" (Q. 11:114). Clearly, this obligatory daily ritual's somewhat vague images have to be made more specific so that nothing will be left to chance. ${ }^{19}$ But where can the necessary information be found if not in the Sunnah? ${ }^{20}$ A vast number of hadiths narrate the specific details on the how, when, and where of the salat.$^{21}$

It is as if by design that whatever has not been stated and detailed in the Qur'an can be found, defined, and reported upon in detail in the Sunnah. ${ }^{22}$ And this does not apply only to salatt, but to many other cases as well. ${ }^{23} \mathrm{In}$ fact, many tenets and legal rulings derived from specific legal implications are deduced from hadith and not mentioned in the Qur' an at all. ${ }^{24}$ For instance, the prohibitions of being married simultaneously to a woman and her aunt, as well eating the meat of predators, were transmitted via the Sunnah. ${ }^{25}$

\section{Obedience to God and to Muhammad}

How does the Qur'an present Muhammad in relationship to God and the Muslims? Does it contain any indicators of how Muhammad lived Islam? Indeed 
it does, for its chapters present how he, as a model practitioner of Islam, lived his life. ${ }^{26}$ His words and deeds receive a very high status in the text. Out of the thirty-five verses researched, twenty-one couple the imperative "obey" with God and Muhammad. Although the wording varies, they consistently convey ați ' $\bar{u}$ Allāh wa ați ' $\bar{u}$ al-rasūl ("Obey God and obey the Messenger"). ${ }^{27}$

One may ask why the Qur'an ties obedience to Muhammad with obedience to God. In the Qur'anic methodology of reasoning, this would be like one of the Sahabah, while engaged in jihad, disregarding Muhammad's directions when it comes to defending the early Muslims. The Qur'an adds that this command is both an act of obedience to God as well as to Muhammad (Q. 8:20). ${ }^{28}$ When the text states an injunction that is to be obeyed, it uses his title al-Rasūl (the Messenger), not his name.

There have been many discourses among Muslim scholars about the difference in meaning between messenger and prophet. In summary, a messenger receives divinely revealed scriptures with new sacred laws, whereas a prophet, who receives only divine revelation, continues to call the people to the sacred law revealed prior to his advent. Thus all messengers are prophets, but not every prophet is a messenger. In the Qur'an, the messengers (viz., Abraham, Moses, David, Jesus, and Muhammad) are referred to as receiving the sacred laws: the Scrolls (Suhuf; Q. 87:19), the Torah (Taurāt; Q. 5:44; 28:43), the Psalms (Zabūr; Q. 4:163), the Gospel (Injīl; Q. 5:46), and the Qur'an (Q. 2:151,252; 4:136), respectively.

Given this fact, does the Qur'an have anything to say about whether his decisions and way of life hold any authority? According to Muslim belief, the use of the plural imperative aț ' $\bar{u}$ (obey) means that God is giving the Muslims a direct order and directive to submit and adhere to His teachings (the Qur'an) and to Muhammad's teachings (the Sunnah). In sum, they interpret obeying Muhammad as adhering to the Sunnah. ${ }^{29}$ The command is a duality, in that there are two lawgivers. Yet Muhammad's authority is not completely independent, for it stems from his status as God's Messenger. His only responsibility is to convey the message from the source: God, the highest and most absolute authority. Aisha Musa describes this as the duality of revelation. ${ }^{30}$

This explicit, direct command often comes in verses immediately following Qur'anic legal rulings. Such an arrangement both encourages and confirms for Muslims that they are expected to adhere to these rulings. For example, the legal rulings against alcohol and gambling are found in the same verse ${ }^{31}$ : "With intoxicants and gambling, Satan seeks only to incite enmity and hatred among you, and to stop you remembering God and prayer. Will you not give them up?" (Q. 5:91). The very next verse states: "Obey 
God and obey the Messenger, and always be on your guard: if you pay no heed, bear in mind that the sole duty of Our Messenger is to deliver the message clearly" (Q. 5:92).

Another quite explicit hukum (legal ruling) forbids usury and is followed with "Beware of the Fire prepared for those who disbelieve. And obey God and the Messenger so that you may be given mercy" (Q. 3:131-32). This hukum exemplifies one aspect of the Qur'anic method of reasoning: the use of contrasts to convince the reader of its rules' wisdom and benefit. In addition, the text intertwines eschatological warnings of punishment for non-adherence. For instance Q. 3:132, which is located between the legal rulings and the command for obedience, warns Muslims that they could be punished in Hell with the same torment prepared for those who have rejected belief if they ignore the prohibition against usury. ${ }^{32}$

This technique juxtaposes images of punishment in the afterlife against a command for obedience embellished with colorful images of eternal divine mercy. This contrasting of opposites, which sheds light and focuses one's attention on the text's argument, is an essential element of the Qur'anic method of reasoning.

\section{Muhammad Clarifies Qur'anic Legal Rulings}

The obligation to obey Muhammad is an oft-revisited Qur'anic concept partly because he taught and demonstrated many ahkām. Thus, his role in conveying the Qur'an and clarifying the meaning of its legal rulings signifies that obeying God and Muhammad are critical matters. ${ }^{33}$ Given that his entire life was a daily demonstration and explanation of the Qur'an's ahkām, his Sunnah parallels or accompanies the Qur'an. ${ }^{34}$ This was one of al-Shafi'i's main argument for the hadith's authority. ${ }^{35}$

Three Qur'anic verses explicitly express this with very similar language:

Say: "Obey God and obey the Messenger. If you turn away, know that he is responsible for the duty placed on him and you are responsible for the duty placed upon you. If you obey him, you will be rightly guided, but the Messenger's duty is only to deliver the message clearly." (Q. 24:54)

So obey God, and obey the Messenger. If you turn away, remember that Our Messenger's duty is only to make plain his message." (Q. 64:12)

Obey Allah, and obey the Messenger, and beware (of evil): if you turn back, know that it is Our Messenger's duty to proclaim (the message) in the clearest manner. (Q. 5:92) 
By design, those practices and legal rulings that the Qur'an does not explicitly explain are often explained by the Sunnah. ${ }^{36}$ Al-Shatibi (d. 790/1388) elaborated upon this general principal of the Shari'ah in great detail in his Al-Muwāfaq $\bar{a} t$, which deals with the objectives of Islamic jurisprudence. ${ }^{37}$

Șalāt and its portrayal in the hadith is a clear example of the Sunnah being a source of rules for acts of worship. The Sunnah is also an authority source for $m u$ 'àmalāt (trade, business transactions, or social life) that may not be directly considered as acts of worship. ${ }^{38}$ This is found in "The Messenger of God is an excellent model (uswah) for those of you who put your hope in God and the Last Day and remember God often" (Q. 33:21). ${ }^{39}$

The word uswah (an exemplar, a model) ${ }^{40}$ infers that Muhammad's life is an example to be followed and a source of law for many aspects of life. ${ }^{41}$ Two different approaches to jurisprudence have been deduced from this verse: (1) it is wäjib (obligatory) to follow the example set by Muhammad in worship and in $m u$ ' àmalat unless additional evidence in the sources designate a specific sunnah as being only mustahabb (praiseworthy or highly recommended) ${ }^{42}$ and (2) that the ruling of following the Sunnah is only mustahabb regarding $m u$ 'ámalāt and thus to be heeded. But it is a compulsory obligation only if additional evidence identifies it as $w \overline{a j} i b .{ }^{43}$ This is deduced from the legal implication of the expression lakum (for those of you), as found in Q. 33:21.

\section{"The Messenger of God is an excellent model for those of you..."}

Those who held the second position interpret this not as an obligatory command, but rather as a highly recommended directive that will gain one rewards if it is observed; however, one is not blamed if he/she ignores it. ${ }^{44}$ A sunnah can only be obligatory if the Qur'anic text contains an unequivocal imperative verb, ${ }^{45}$ as opposed to the first position, which asserts that the verse itself is enough to prove that all Muslims have to adhere to the Sunnah in all aspects of their life. ${ }^{46}$ So here we can see two trends of juristic opinion based upon two different interpretations of how the Qur'an views the Sunnah. This clearly highlights its importance to understanding how Islamic practice is defined.

\section{Muhammad and the Qur'anic Etiquette for Muslim Women}

The Qur'anic etiquette regarding Muslim women is a multifaceted doctrine that includes many ahkām. One is confirmed and emphasized by being sealed 
with a command to obey God and Muhammad. As Q. 33:33 states, it is wājib for a Muslim woman to stay in the safety and security of her home as much as possible. At the same time, this ruling is flexible enough to allow them to go outside for necessities (e.g., maintain strong family ties; do good deeds; and pursue business, education, or other constructive endeavors) ${ }^{47}$ Although this injunction's language is worded as a directive specifically for Muhammad's wives, it is seen as conveying a general message to all Muslim women. It is articulated in such a manner to honor Muhammad's wives. ${ }^{48}$

Before its revelation, Muhammad had been giving etiquette guidelines to Muslim women: dress modestly and do not mix freely with men, as was the pre-Islamic norm. ${ }^{49}$ This sunnah was then given legal authority by a revelation that clearly forbids Muslim women to observe the previously accepted norms:

And stay in your houses, and do not display yourselves (tabarruj) like that of the times of ignorance, and perform salat and give zakat (the prescribed charity) and obey God and His Messenger. (Q. 33:33)

Tabarruj literally means for a woman to adorn herself with clothing that is enticing, alluring, and intended to arouse a man's lust..$^{50}$ This term is used to communicate a very specific legal implication: no premarital romance and open social intermingling between the sexes, specifically non-mahrams (men whom a woman could marry). This term also refers to a type of walk or strut that some pre-Islamic Arab women employed to catch a man's attention: swaying her hips in an alluring fashion. ${ }^{51}$

The verse closes with three commands: perform șalāt, give zakat, and obey God and Muhammad. Each imperative-form verb is conjugated in the feminine plural form to directly address Muslim women. This etiquette is, first, a defensive technique designed to minimize flirtatious conversations and social contact; second, to reduce the possible causes of extra-marital affairs; and third, to promote the concept of female modesty by contrasting it to a woman who flaunts her natural beauty to attract men. This woman-only legal ruling, an internationally visible aspect of Islamic society, ends with another repetition of "Obey God and obey the Messenger."

\section{The Judicial Role of Muhammad}

The Qur'an directs Muslims to settle their disagreements by referring them to Muhammad (Q. 4:64-65, 105; 24:51; 33:36) In addition, it commands him to judge, decide, and give legal rulings when requested to do so: 
We have sent down the scripture to you (Muhammad) with the truth so that you can judge between people in accordance with what God has shown you. Do not be an advocate for those who betray trust. (Q. 4:105)

When the true believers are summoned to God and His Messenger in order for him to judge between them, they say, "We hear and we obey." These are the ones who will prosper: whoever obeys God and His Messenger stands in awe of God and keeps his duty to Him will be triumphant. (Q. 24:51-53)

The first generation of Muslims could do this face to face with Muhammad. In fact, in certain cases he was asked to give legal rulings and judgments between the disputing parties. ${ }^{53}$ For the following generations, this conveys the concept of seeking solutions, guidelines, and legal rulings from both the Qur'an and the Sunnah. To "return to Muhammad" means to refer to his Sunnah (Q. 4:59). ${ }^{53}$ The Qur'anic method of reasoning tries to convince Muslims that adhering to both the Qur'an and the Sunnah is superior to rejecting their legal rulings. ${ }^{54}$ Several verses (e.g., Q. 4:64-65; 5:42, 49; 33:36) contrast such a refusal with belief. For example:

By your Lord, they will not be true believers until they let you decide between them in all matters of dispute and find no resistance in their souls to your decisions, accepting them totally. (Q. 4:65)

Based on this verse, it can be said that a Muslim who does not accept Muhammad's legal rulings could be seen as engaging in nifāq (hypocrisy) ${ }^{55}$ In general, Islam's commands and prohibitions are seen as obligatory, especially when it comes to resolving disputes. ${ }^{56}$

O you who believe! Obey God and the Messenger and those in authority among you. If you are in a dispute in any matter, refer it to God and the Messenger, if you truly believe in God and in the Last Day. (Q. 4:59)

Accepting Muhammad's legal rulings is thus seen as a basic part of being Muslim. ${ }^{57}$ According to the Qur'an, all prophets are sacrosanct, inviolable, and sent by God to guide humanity and therefore are to be followed. This verse contains the legal implication that all Muslims must implement Islamic teachings and rules, from the Qur'an and/or from the Sunnah, as best they can, and especially so in regard to worship and legal disputes. ${ }^{58}$

Qur'an 4:59 provides an outline of the basic principles (or sources) of usūl al-fiqh. ${ }^{59}$ To "refer to God" communicates that the Qur'an is a primary source of law, whereas to "obey (or refer to) the Messenger" means to follow 
and apply Muhammad's sunnah as a source of law. ${ }^{60}$ The phrase $u l \bar{u}$ al-amr minkum (those in authority among you) is given quite a few different (but related) interpretations: Islamic scholars, rulers, influential people, experts, the Companions, and Abu Bakr and Umar. ${ }^{61}$ These interpretations can be seen as referring to a third source of law, ijma $\bar{a}^{\text {' }}$, defined as the consensus of legal opinion of all Muslim scholars at any particular time (after Muhammad's death, of course) who are knowledgeable and academically competent enough to deduce legal rulings from the Islamic sources. ${ }^{62}$

\section{Muhammad and the Consecration of Marriages}

The judicial role of Muhammad also included the authority to consecrate marriages. ${ }^{63}$ Several of the marriages that he sanctified contradicted his society's norms: a marriage between a male Muslim slave or a freed former slave and a free Arabian woman from a highly respected family ${ }^{64}$ : Bilal + the sister of Abdur Rahman ibn Awf, Zayd ibn Harith + Zaynab bint Jahsh al-Asdia, al-Miqdad ibn al-Aswad + Dabaa bint al-Zubayr, and Abu Ludhiana + Fatima bint al-Walid ibn Atba. ${ }^{65}$

These unions speak volumes about Islam's principles of equality and unity. ${ }^{66}$ However, each wedding was initially greeted with disdain by members of the bride's family, the early Muslim community, and/or Madinah's general population, not to mention the wife herself (viz., Zaynab). ${ }^{67}$ In fact, some jurists insist that the principle of $k a f a \bar{a}^{\prime} a h$ (marital suitability) is essential, that it actually requires a person with a very honorable lineage to marry only a person with a comparable social status. ${ }^{68}$ But it would appear that the stronger opinion is that the only obligatory kafa ' $a h$ is religious suitability. To support this view, al-Qurtubi cites Q. 2:221, 28:26-28, and 33:36. ${ }^{69}$

Qur'an 33:36 is perhaps the strongest evidence for this opinion, since it was revealed as a crystal clear example focused on and stressed by Muhammad. The account is as follows. When Muhammad asked Zaynab to marry Zayd ibn Harith, his emancipated slave, she refused on the grounds that she was of noble lineage. ${ }^{70}$ The following verse was revealed shortly thereafter ${ }^{71}$ :

When God and His Messenger have decided on a matter that concerns them, it is not fitting for any believing man or woman to claim freedom of choice in that matter: whoever disobeys God and His Messenger is far astray. (Q. 33:36)

The hukum deduced here is that a Muslim could not ignore Muhammad's directives and commands during his lifetime. This authority was then understood to be transferred to his Sunnah after his death. ${ }^{72}$ 


\section{Muhammad Gives Legal Rulings to the Ahl al-Kitab}

Another of Muhammad's judicial roles was to hand down legal rulings in cases brought to him by the Ahl al-Kitab (Jews and Christians). Moreover, the Qur'an describes itself as both confirming and protecting the previous revelations:

We sent to you (Muhammad) the Scripture with the truth, confirming the Scriptures that came before it and with final authority over the past Scriptures. So judge between them according to what God has sent down. Do not follow their whims, which deviate from the truth that has come to you. We have assigned a law (shir'atan) and a path (minhājan) to each of you. If God had so willed, He would have made you one community, but He wanted to test you through that which He has given you, so race to do good: you will all return to God and He will make clear to you the matters you differed about. (Q. 5:48)

This oft-repeated theme is an important method of Qur'anic reasoning, for through it the text shows and argues its authenticity. The Qur'an declares that each people has been sent a scripture (viz., the Torah, the Gospels and the Qur'an) that conveys a religious way of life. The terms employed here, shir'atan (a law, legislation for a religious way of life, a synonym for Sunnah) and minhajjan (a clear continuous way), ${ }^{73}$ help explain why the Sunnah is understood to be a source of Islamic law and that each people who received a revealed scripture was also given a law, a way of life. Thus the Qur'an was sent to Muhammad, and his Sunnah shows how to implement it in daily life.

Once, at the request of some of Madinah's prominent Jews, Muhammad ruled in the case of a Jewish woman from a highly respected family who had been caught committing adultery. ${ }^{74}$ His first question was what does the Torah have to say about extra-marital affairs? ${ }^{75}$ Unconvinced by what he was told, as their answer did not carry the gravity of being a greater sin, he asked them to bring the Torah. During the ensuing discussion, the Jews' attempt to conceal the relevant verse was uncovered. Consequently, it was discovered that both scriptures prescribed the same penalty: capital punishment. After their guilt was confirmed, both individuals were sentenced. ${ }^{76}$

The Qur'an allows a choice between two options:

If they (Jews and Christians) come to you (Muhammad) for judgment, you can either judge between them, or decline - if you decline, they will not 
harm you in any way, but if you do judge between them, judge justly: God loves the just. (Q. 5:42)

The Qur'an defines itself as a protector of the earlier revelations' validity, confirms the prophets mentioned in the Old and New Testaments, and bears witness to their messages. ${ }^{77}$ Yet it also delivers a law that in several ways differs from the one found in the earlier scriptures. ${ }^{78}$ Thus there is a certain duality, for while the Qur'an states that it is the final divinely revealed scripture, it consistently confirms that its predecessors (e.g., the Torah, the Gospels, and the Psalms of David) were earlier-revealed divine scriptures. The Qur'an even announces the existence of two scriptures unknown to Christendom: one revealed to Abraham and one to Noah. Furthermore, declaring itself to be the final version, the Qur'ans asserts that it was sent to update the earlier revelations. Thus it both verifies the Bible's past authenticity and declares that these scriptures, in a sense, had been scheduled for an updating.

Qur'an 5:42, a critical rhetorical question, echoes with disdain and amazement at how illogical it was for the Jews to seek a legal ruling from Muhammad when it was already in the Torah. ${ }^{79}$ The question employs yuhakkimunaka (they come to you for judgment) conveying a plural subject: "But why do they come to you for judgment (yuhakkimunaka) when they have the Torah with God's judgment, and even then they still turn away..." (Q. 5:43).

It must be emphasized that the Abrahamic faiths' basic, original foundation is perceived as one: tawhi $\bar{i}$ (monotheism). ${ }^{80}$ Thus their roots are unified, even though their religious laws differ. Some of the clearest evidence for this is found in Șahịh al-Bukhārī:

Narrated by Abu Hurayrah: "I heard the Messenger of God say: 'Both in this world and in the Hereafter, I am the nearest of all the people to Jesus, the son of Mary. The prophets are paternal brothers; their mothers are different, but their religion is one." $" 81$

This hadith confirms the Qur'anic principle that the prior prophets were bearers of an authentic message from God, deliverers of a divine scripture. The Qur'anic claim that Muhammad was authorized to judge between the Ahl al-Kitab stems from his status as the final member of a long line of prophets whose messages had the same source. Therefore, it is argued that their acceptance of his legal rulings is the same as their acceptance of their own prophets. 


\section{Qur'anic Legal Terminologies and the Sunnah}

Yuhillu (to make something lawful or religiously permissible) and yuharrimu (to make unlawful or religiously prohibited) are legal terms in the form of transitive verbs, with Muhammad as their subject. ${ }^{82}$ As the following verse proclaims:

Those who follow the Messenger - the unlettered Prophet they find described in the Torah that is with them and in the Gospel - who commands them to do right and forbids them to do wrong, who makes good things lawful to them (yuhillu lahumu al-tayyibāti) and bad things unlawful (yuharrimu 'alayhimu al-khabä'ithah) and relieves them of their burdens and the iron collars that were upon them. So it is those who believe in him, honor and help him and who follow the light which has been sent down with him, who will succeed. (Q. 7:157)

The verse details Muhammad's legalization of that which is beneficial and his prohibition of that which is harmful. ${ }^{83}$

The Qur'an here refers to the pre-Islamic Arab tradition of dedicating certain types of cattle bearing specific characteristics to their deities. ${ }^{84}$ The text also refers to Judaism's religious laws by analogy as aghläl (iron collars), since they were quite difficult to observe in full. ${ }^{85}$ For instance, when an observant Jew's clothing was stained with urine, the polluted part had to be cut off instead of washed. In addition, male Jews were forbidden to eat or even sit with a menstruating Jewess, as well as to eat meat that contained visible veins. Such religious laws are described as a bit harsh, and the Qur'anic method of reasoning argues for their abandonment. ${ }^{86}$

The next two terms with legal implications are nahäkum (he forbids you) and atākum (he gives you) ${ }^{87}$ :

Whatever gains God has turned over to His Messenger from the inhabitants of the villages belong to God, the Messenger, kinsfolk, orphans, the needy, the traveller in need - this is so that they do not circulate among those of you who are rich - so accept whatever the Messenger gives you (atākum) and abstain from whatever he forbids you (nahākum). Be mindful of God: God is severe in punishment. (Q. 59:7)

Here, the legal authority given to Muhammad is the exclusive use and/or right to distribute the wealth acquired peacefully from non-Muslims. ${ }^{88}$ This incident occurred when God revealed that Muhammad and his community could benefit from the property of Bani Nadir, a Jewish tribe that had traded all of its homes and property for safe passage out of their village after they 
were reported to have reneged on a treaty. This was agreed to near Madinah. Moreover, the verse also imparts a more general meaning of avoiding the prohibitions and adhering to the commands recorded in the Sunnah. ${ }^{89}$

Hudūd Allāh (prescribed boundaries, religious limits and decrees) is a Arabic legal expression formed from the plural noun for hadd.$^{90}$ This phrase, which only appears twice in the Qur'an, immediately follows the verses that detail some of the inheritance laws in order to emphasize their importance by linking them to the command to obey God and Muhammad (Q. 4:7-12, 1314). ${ }^{91}$ Even though these verses follow these very specific laws, the term can be understood as incorporating the more general meaning of calling upon Muslims to adhere to Islamic legal rulings. ${ }^{92}$ The Qur'anic method of reasoning ends these verses with an eschatological warning of punishment for disregarding the inheritance laws, in contrast to the promise of reward in the gardens of the afterlife for implementing them..$^{93}$

These are the bounds set by God (hudūd Allāh): God will admit those who obey Him and His Messenger to Gardens graced with flowing streams, and there they will stay - and that is supreme triumph! But those who disobey God and His Messenger, and overstep His limits will be consigned by God to the Fire, and there they will stay - a humiliating torment awaits them! (Q. 4:13-14)

Khașim (acting as a defendant or advocating), an intensive form of the active participle, ${ }^{94}$ appears in Q. 4:105, which was revealed while Muhammad was making a legal decision. He initially inclined toward accepting Tu'mah ibn 'Ubayriq's plea that he had not stolen a shield and hid it in the house of a Jewish man in Madinah. But unbeknownst to him, a witness later testified that he had seen Tu'mah carrying something that evening..$^{95}$ When asked about it, he passionately denied the theft and plotted with others to accuse this Jewish neighbor, in whose house the stolen item had been conveniently "discovered." Even after this, several of his clan members continued to assert his innocence. As a result, his defense began to be considered plausible, especially since the shield has been "recovered" from his neighbor's house. ${ }^{96}$ This circumstantial evidence, plus the multiple character testimonies from Tu'mah's clan, was beginning to have the desired effect. ${ }^{97}$ However, the following verse was revealed before Muhammad ruled ${ }^{98}$.

We have sent down the Scripture to you (Muhammad) with the truth so that you can judge between people in accordance with what God has shown you. Do not be an advocate (khașim ) for those who betray trust. (Q. 4:105) 
This reported reason for its revelation was to correct Muhammad's preliminary inclination. ${ }^{99}$ Without this 'ilm al-ghayb (knowledge of the Unseen), Muhammad might have handed down an unjust verdict. Thus the Qur'anic text is reported to have guided and adjusted his decision. ${ }^{100}$ Two important legal principles can be deduced here: (1) The Shari'ah does not consider circumstantial evidence to be conclusive proof, which can be arrived at only by either a witness or a confession, and (2) a Muslim cannot provide legal defense counsel for anyone whose innocence is doubted by the lawyer or the advocate. ${ }^{101}$ Both of these points represent some of the key differences between the Shari'ah's basic principles and the common legal concepts in many western legal systems.

Qur'an 4:65 contains three important terms that have direct legal implications. The verse proclaims that accepting Muhammad's legal decisions is a prerequisite to Muslim faith. In other words, one cannot be a faithful Muslim if one rejects Muhammad as a prophet and a propagator of Islam and its law.

By your Lord, they will not be true believers until they let you decide (yuhakkimūka) between them in all matters of dispute (shajara), and find no resistance in their souls to your decisions (qadayta), accepting them totally. (Q. 4:65)

The first legal term, yuhakkimūka (a group of people are enjoined to seek Muhammad's legal judgements), is mentioned in Q. 5:43 above. It conveys a plural subject and comes from the root verb hakama (to give legal judgements or to have authority). ${ }^{102}$ The second term, shajara (to dispute), ${ }^{103}$ refers to Muhammad's being called upon to judge the quarrels and disputes that arise among people. Moreover, the verse comes in a conditional sentence, namely, that true complete faith is only reached by accepting his legal authority and rulings. The third term, qadayta (the past tense form of to judge, issue a verdict, or pass a sentence), is a transitive verb. ${ }^{104}$ These terms are employed to convey the relationship among Muhammad, his legal authority, and faith in Islam. The verse conveys that part of the Muslim faith is to embrace Muhammad's legal authority, which accompanies the Qur'an and its revelation and, after his death, his Sunnah.

The classical Arabic term bāya 'a (to swear fealty, to pledge allegiance or loyalty), two conjugations of which appear in Q. 48:10, ${ }^{105}$ functions as the effective cause of an eschatological promise of heavenly reward for approximately 1,500 Companions who swore their loyalty to Muhammad at Hudaybiyah. ${ }^{106}$ Reports of the exact wording vary slightly, which may not be too surprising. Many people were there at the same time, and each man placed 
his hand on top of Muhammad's hand and stated their pledge, while Muslim women made their pledge only verbally and not hand to hand with Muhammad. ${ }^{107}$ Their pledges were given in the midst of great excitement and enthusiasm, for Hudaybiyah was approximately only sixteen kilometres away from Makkah's entrance. ${ }^{108}$ At that time, they did not know if they would be allowed to make a peaceful pilgrimage or would have to fight. ${ }^{109}$

Even though the Muslims came with the intention of engaging in a peaceful hajj, they assumed that Uthman, their emissary to the Makkans, had been apprehended; many thought he had been killed. ${ }^{110}$ Thus some worded their pledges as follows: "I will never flee the battle"; others reported that they pledged "to fight to the death." 111 When some of the polytheists who witnessed went home and told their fellow Makkans about the bay ' $a$ h, a ten-year peace treaty was then negotiated with Muhammad. ${ }^{112}$

The verse is inlaid with a metaphor that helps to complete a more accurate image of why the Sunnah is accorded such religious and legal authority ${ }^{113}$ :

Those who pledge loyalty to you (Muhammad) are actually pledging loyalty to God Himself - God's Hand is placed on theirs - and anyone who breaks his pledge does so to his own detriment: God will give a great reward to the one who fulfils his pledge to Him." (Q. 48:10)

The significance of Muhammad's role is that although the pledge was made to him, its actual meaning transcends what may be perceived as just a vow to a local Arab leader 1,400 years ago. The bay 'ah of Hudaybiyah imports that this loyalty oath carried the same weight and significance as if it had been made to God directly. ${ }^{114}$ The Qur'anic method of reasoning drives home this point allegorically: "God's hand (yad Allahh) is above theirs" (Q. 48:10).

Yad Allāh represents the victory, strength, triumph, divine assistance, and blessings of God that guided the Companions to make and fulfill this pledge. ${ }^{115}$ In fact, they firmly believed that its reward was one that only God had the power to give: an afterlife in eternal paradise. ${ }^{116}$ Thus a second name of this event is bay 'at al-ridwān (the pledge that earned God's favor). ${ }^{117}$

\section{Conclusion}

The early Muslim community held tightly to and passed down from generation to generation the principles that Muhammad had taught and implanted within them. Later on, these original Islamic beliefs and practices became the detailed and diverse branches of the Islamic religion, society, and culture. It began with the Qur'an and the Sunnah, the two roots that grew into the larger tree of Is- 
lamic civilization. In order to best understand how the Qur'an perceives the Sunnah, the discussion first should be properly placed at the beginning of Islamic society. To make a full study of how it engages the Sunnah, one is required to undertake a detailed investigation of Qur'anic Arabic and the context of the verses that mention Muhammad.

Although the bay'ah of Hudaybiyah was a solemn covenant of loyalty with Muhammad, it also conveyed allegiance to the divine. ${ }^{118}$ In other words, Muhammad's authority inferred a direct connection between a prophet and God. The fealty of both the men and the women to Muhammad was confirmed by an oath and for the men by a symbolically obedient hand gesture, but God's hand was above them all, overseeing and confirming that their loyalty to His Messenger pleased Him (Q. 48:10).

The Qur'an reflects the relevance of Muhammad's Sunnah to the Islamic way of life in many ways: as a model to be followed (Q. 33:21), one who is enjoined to judge with justice (Q. 4:105), one explicitly commanded to transmit the principals of Islam's spiritual teachings (e.g., morality, character building, belief in the afterlife, the Day of Judgment, and legal rulings) (Q. 5:92, 24:54, 64:12), and commanded to be a just legislator (Q. 7:157). If all of these Qur'anic indicators of the Sunnah's authority were not sufficient, the text also confers upon Muhammad the authority to consecrate marriages for the poorest members of his society (Q. 33:36).

The Qur'an provides undeniable evidence of the Sunnah's authority in Islamic law. This proof is quite clear when examining these thirty-five verses that mention Muhammad. Islam's legal authority comes from both the Qur'an and the Sunnah; in addition, it encompasses virtually all aspects of the Islamic way of life. I close with an $\bar{a} t h \bar{a} r$ (a saying of a Companion or an early Muslim):

Alqama narrated: Abdullah ibn Mas'ud said, "Allah curses those ladies who practice tattooing and those who get themselves tattooed, and those ladies who remove the hair from their faces and those who make artificial spaces between their teeth in order to look more beautiful whereby they change God's creation." His saying reached a lady from the Bani Asad called Umm Ya'qub, who came to Abdullah and said, "I have come to know that you have cursed such-and-such ladies." He replied, "Why should I not curse those whom God's Apostle has cursed and who are cursed in God's Book?" Umm Ya'qub said, "I have read the whole Qur'an, but I did not find in it what you say." "He said, 'Verily, if you have read it, you have found it. Didn't you read: So accept whatever the Messenger gives you, and abstain from whatever he forbids you?"” (Q. 59:7) ${ }^{119}$ 
Table 1: Qur'anic verses referring to Muhammad's Sunnah

$\begin{array}{lll}\text { Sūrah Name } & \text { Ayāt } & \text { Sūrah Period } \\ \text { Āli ‘Imrān } & 3: 32,132 & \text { Madinan } \\ \text { Al-Nisā' } & 4: 13-14,59, & \text { Madinan } \\ & 64-65,69,80,105 & \\ \text { Al-Mā'idah } & 5: 42-43,48-49,92 & \text { Madinan } \\ \text { Al-A'rāf } & 7: 157 & \text { Makkan } \\ \text { Al-‘Anfāl } & 8: 1,20,46 & \text { Madinan } \\ \text { Al-Tawbah } & 9: 71 & \text { Madinan } \\ \text { Al-Nūr } & 24: 51-52,54,56 & \text { Madinan } \\ \text { Al-'Ahāāb } & 33: 21,33,36,71 & \text { Makkan } \\ \text { Muhammad } & 47: 33 & \text { Madinan } \\ \text { Al-Faṭ̣ } & 48: 10,17 & \text { Madinan } \\ \text { Al-Hujurāt } & 49: 14 & \text { Madinan } \\ \text { Al-Mujādilah } & 58: 13 & \text { Madinan } \\ \text { Al-Hashr } & 59: 7 & \text { Madinan } \\ \text { At-Taghābun } & 64: 12 & \text { Madinan }\end{array}$

\section{Endnotes}

1. M. A. S. Abdel Haleem, The Qur'an: A New Translation (Oxford: Oxford University Press, 2004), 9; Wael B. Hallaq, "Law and the Qur'an," Encyclopaedia of the Qur'an (Washington, DC: Georgetown University, 2009); M. H. Kamali, Principles of Islamic Jurisprudence (Cambridge: 2003), 16; Suyuti, It qān fi 'Ulūm al-Qur'ān (Beirut: 2004), 4, 8.

2. R. Bell, Introduction to the Qur'an (Edinburgh 1953), xi, 215-40; M. A. Draz, Introduction to the Qur'an (London 2000), 127; Kamali, Principles, 18.

3. Muhammad Nasir al-Din Albani, Al-Hadith Hujjah bi Nafsihi fì al- 'Aqā'id wa al-Ahkām (Riyadh: 2005), 13; M. M. Azami, Studies in Hadith Methodology and Literature (Indianapolis: 1992), xvii; Kamali, Principles, 58; Ibn Salah alShahrazuri, "Introduction to Science of Hadith," in An Introduction to the Science of the Hadith: Kitāb Ma 'rifat Anwā' "Ilm al-Hadith, trans. Eerik Dickinson (Reading: 2006), 35; G. H. A. Juynboll, “Sunna," Encyclopaedia of the Qur'ān (Washington, DC: Georgetown University Press, 2009).

4. Azami, Studies in Hadith Methodology, 3; M. Z. Siddiqi, Hadith Literature: Its Origin, Development, and Special Feature (Cambridge: 1993), 2; Juynboll, "Sunna." Sunnah appears sixteen times in the Qur'an, according to Azami, Siddiqi, and my own research; Junyboll writes that it appears eighteen times.

5. M. A. S. Abdel Haleem, Understanding the Qur'an (London: 2008), 6; B. Philips, Usool al-Hadeeth: The Methodology of Hadith Evaluation (New York: 
2007), 3; J. Robson, “Hadith,” Encyclopaedia of Islam, 2d ed., ed. Bearman, Th. Bianquis, C. E. Bosworth, E. van Donzel \& W. Heinrichs (Brill: 2009); Goitein, S. D., Studies in Islamic History and Institutions (Leiden: 1966), 25.

6. Albani, Al-Hadith Hujjah, 13; al-Maqdasi, Jamal al-Din Yusef ibn Hassan, Bulghah al-Hadìth ilā 'Ulūm al-Hadìth (Beirut: 1995), 18-19; Azami, Studies in Hadith Methodology, xvii; Siddiqi, Hadith Literature, 2.

7. Albani, Al-Hadìth Hujjah, 25; Jonathan Brown, The Canonization of al-Bukhari and Muslim: The Formation and Function of the Sunni Hadith Canon (Leiden and Boston: Brill, 2007), 72; Azami, Studies in Hadith Methodology, 5; Kamali, Principles, 61; Wael B. Hallaq, A History of Islamic Legal Theories: An Introduction to Sunni Usul al-Fiqh (Cambridge: Cambridge University Press, 1997), 11; Philips, Usool al-Hadeeth, 4.

8. Hallaq, A History of Islamic Legal Theories, 18, 20-21; Kamali, Principles, 6263, 78, 85; Scott C. Lucas, Constructive Critics, Hadith Literature, and the Articulation of Sunni Islam (Leiden: 2004), 12.

9. Musa, Aisha Y. "Al-Shafi'i, the Hadith, and the Concept of the Duality of Revelation," Islamic Studies 46, no. 2 (summer 2007): 191.

10. Jonathan Brown, "Critical Rigor vs. Juridical Pragmatism: How Legal Theorists and Hadith Scholars Approached the Backgrowth of Isnads in the Genre of Ilal al-Hadith," Islamic Law and Society, no. 14 (Koninklijke, Brill NV, Leiden: 2007), 4; Lucas, Constructive Critics, 368-69.

11. Lucas, Constructive Critics, 368-69.

12. Musa, "Al-Shafi'i," 175-77.

13. Brown, "Critical Rigor vs. Juridical Pragmatism," 4, 6; Lucas, Constructive Critics, 368-69.

14. Hallaq, Islamic Legal Theories, 18; Kamali, Principles, 96-97.

15. Brown, "Critical Rigor vs. Juridical Pragmatism," 305-06; Butrus Abu-Manneh, "Salafiyya and the Rise of the Khâlidiyya in Baghdad in the Early Nineteenth Century," Die Welt des Islams, New Series, 43, no. 3, Transformations of the Naqshbandiyya, 17th-20th Century (Brill: 2003), 349-72, 350; Kamali, Principles, 493; Lucas, Constructive Critics, 41-42; Scott C. Lucas, "Legal Principles of Muhammad Ibn Ismail Al-Bukhari and Their Relationship to Classical Salafi Islam," Islamic Law and Society 13, no. 3, 200, 290-91; Itzchak Weismann, "Between Sufi Reformism and Modernist Rationalism: A Reappraisal of the Origins of the Salafiyya from the Damascene Angle," Die Welt des Islams, 41, no. 2 (Brill: 2001): 206-37, 211; Quintan Wiktorowicz, "The Salafi Movement in Jordan," International Journal of Middle East Studies 32, no. 2 (2000): 219-40, 219.

16. Albani, Al-Hadith Hujjah, 49-50, 67-68; Lucas, Legal Principles, 295; Philips, Usool al-Hadeeth, 93; Ibn Salah al-Shahrazuri, "Introduction," 58, 65.

17. Kamali, Principles, 105; Abdul Hakim I. Matroudi, The Hanbali School of Law and Ibn Taymiyyah (London 2005), 47, 60.

18. G. Monnot, "Salāt." Encyclopaedia of Islam, 2d ed.. 
19. Albani, Al-Hadith Hujjah, 25; James Robson, Muslim Tradition: The Question of Authenticity (Manchester: 1952), 1.

20. Muhammad ibn Jarir al-Tabari, Jāmi ' al-Bayān 'an Ta 'wīl aya al-Qur'ān: Tafsīr al-Tabarī (Cairo: 2007), 7:6078.

21. Bukhari, Muhammad ibn Isma'il, Șah̄ị al-Bukhārī (Riyadh: 1999),1:211-79, 297-331, 393-459; Muslim ibn al-Hajjaj, al-Qushayri, Șaḥ̄h Muslim, 206-83; Monnot, G. "Șalāt," Encyclopaedia of Islam.

22. Al-Shatibi, Ibrahim M. M. Al-Muwāfaqāt (Dammam: 2003), 325; Al-Juyni, 'Abd al Malik ibn 'Abd Allah, Matin al Waraqāt (Riyadh: 2002),11-12.

23. Albani, Al-Hadìth Hujjah, 25, 28; Ibahim, Saydi Abd Allah ibn al-Hajj, Murāqib al-Sa 'üd (Cairo: 2003), 80, al-Maqdasi, 'Abd Allah ibn Ahmad Ibn Qudama, Rawḍat al-Nātẓirīn wa Janat al-Manāẓir (Beirut: 2009),196-97; Kamali, Principles, 69; Musa, "Al-Shafi'i," 189.

24. Al-Shatibi, Al-Muwāfaqāt, 4:320; Kamali, Principles, 83-84.

25. Al-Shatibi, Al-Muwāfaqāt, 4:323; Al-Shinqiti, Muhammad al-Amin ibn Muhammad, Naẓru al-Warūd 'alā Murāqib al-Sa 'ūd (Beirut: 2004), 202; Lowry, Joseph E., "The Legal Hermeneutics of al-Shafi 'i and Ibn Qutayba: A Reconsideration," Islamic Law and Society 11, no. 1 (2004): 22.

26. Azami, Studies in Hadith Methodology, 6.

27. See Q. 3:32, 3:132, 4:14, 4:59, 4:64, 4:69, 4:80, 5:92, 8:1, 8:20, 8:46, 24:52, 24:54, 33:33, 33:36, 33:71, 47:33, 48:17, 49:14, 58:13, 64:12.

28. Al-Razi, al-Fakhr al-Din Muhammad ibn 'Umar, Tafsīr al-Kabīr wa Mafātīh al-Ghayb (Beirut: 1983), 5:530.

29. Ibn 'Adil, 'Umar ibn 'Ali al-Dimashqi al-Hanbali, Al-Lubab fì 'Ulūm al-Kitāb (Beirut: 1998), 6:441-51; Mawardi, Al-Nukat wa al- 'Uyūn (Kuwait: 1982),1:40001; Musa, “Al-Shafi'i," 166; Razi, Tafsīr al-Kabīr, 3:370; Tabari, Jāmi ‘ al-Bayān, 3:2393; Tha'labi, 'Abd al-Rahman, Al-Jawāhir al-Hisān fì Tafsìr al-Qur'ān (Beirut: 1996), 1:360-61; Qurtubi, Mukhtār Tafsīr al-Qurtubī, 5:259-61.

30. Musa, "Al-Shafi'i," 166.

31. Ibn 'Adil, Al-Lubab, 7:509; Razi, Tafsīr al-Kabìr, 3:659; Tabari, Jāmi ' al-Bayān, 4:3005; Muhammad ibn Ahmad al-Ansari al-Qurtubi, Mukhtār Tafsīr al-Qurtubī: Al-Jāmi 'li Ahkām al-Qur'ān (Cairo: 1977), 6:293.

32. Zamakhshari, Mahmud ibn 'Umar, Al-Kashshāf 'an Haqā'iq Ghawāmid alTanzīl wa 'Uyūn al-Aqāwīl fì Wujūh al-Ta'wīl (Egypt: 1953), 1:463. (Imam Hanifa said this verse was the most frightening one in the entire Qur'an.)

33. Tha'labi, Al-Jawāhir al-Hisān 1:369; Razi, Tafsīr al-Kabīr, 3:396.

34. Tabari, Jāmi` al-Bayān, 7:6078.

35. Musa, "Al-Shafi'i," 189.

36. Ibn Kathir, Tafsīr, 3:2007; Razi, Tafsīr al-Kabīr, 18:26; Qurtubi, Mukhtār Tafsīr al-Qurtubī, 18:140.

37. Al-Shatibi, Al-Muwāfaqāt, 4:320.

38. Muhammed al-Busairi, A Dictionary of Islamic Juristic Terminologies (Khartoum: 2007), 126; Hans Wehr, A Dictionary of Modern Written Arabic (London: 1980), 646. 
39. Ibn Kathir, Tafsīr Ibn Kathīr (Riyadh: 1999), 3:2234.

40. Muhammad Abdel Haleem, Arabic English Dictionary of Qur'anic Usage (with Elsaid Badawi) (Leiden: 2008), 18; 'Abd al-Mun'im ibn Muhammad ibn al-Furs al-Gharnati, Ahkām al-Qur'ān (Beirut: 2006), 3:423; Mawardi, Al-Nukat, 3:314; Tabari, Jami ‘ al-Bayān, 8:6632; Hadith, 29; Zamakhshari, Al-Kashshāf, 3:256.

41. Ibn al-Furs, Ahkām, 3:423; Ibn Kathir, Tafsìr, 3:2234; Jassas, Ahmad ibn 'Ali, Ahkām al-Qur'ān (Istanbul: 1920) 3:355; Mawardi, Al-Nukat, 3:314-15; Tabari, Jami ‘ al-Bayān 8:6632-35; Qurtubi, Muhammad ibn Ahmad, Al-Jāmi ‘ li Ahkām al-Qur'ān (Cairo: 1977), 14:155-56; Zamakhshari, Al-Kashshāf, 3:256-57.

42. Jassas, Ahkām, 3:355-56; Mawardi, Al-Nukat, 3:314-15.

43. Jassas, Ahkām, 3:355-56; Mawardi, Al-Nukat, 3:314-15; Qurtubi, Mukhtār Tafsīr al-Qurtubì, 14:155-56.

44. Jassas, Ahkām, 3:355-56.

45. Ibid 3:356.

46. Ibn 'Adil, Al-Lubab, 7:509-10; Ibn al-Furs, Ahkām, 3:423; Ibn Kathir, Tafsīr, 3:2234.

47. Ibn 'Adil, Al-Lubab, 15:546-47; Ibn Kathir, Tafsīr, 3:2243; Jassas, Ahkām, 3:360; Mawardi, Al-Nukat, 3:322-3; Razi, Tafsīr al-Kabìr, 6:783; Tabari, Jāmi ‘ al-Bayān, 8:6658; Tha'labi, Al-Jawāhir al-Hisān, 2:573-74; Qurtubi, Mukhtār Tafsìr al-Qurtubī, 14:179; Zamakhshari, Al-Kashshāf, 3:260.

48. Ibn Kathir, Tafsìr, 3:2244-6; Jassas, Ahkām, 3:360; Tabari, Jāmi ‘ al-Bayān, 8:6663; Tha'labi, Al-Jawāhir al-Hisān, 2:573-74; Qurtubi, Mukhtār Tafsīr alQurtubī, 14:179.

49. Tabari, Jāmi ‘ al-Bayān, 8:6656.

50. Abdel Haleem, Arabic English Dictionary, 85; Al-Busairi, Dictionary, 17.

51. Ibn Kathir, Tafsīr, 3:2244-45; Jassas, Ahkām, 3:360; Mawardi, Al-Nukat, 3:32223; Razi, Tafsīr al-Kabīr, 6:783; Tabari, Jāmi ‘ al-Bayān, 8:6658; Qurtubi, Mukhtār Tafsīr al-Qurtubī, 14:179-80.

52. Ibn 'Adil, Al-Lubab, 6:465; Ibn Kathir, Tafsīr, 1:714-15; Mawardi, Al-Nukat, 1:404; Razi, Tafsìr al-Kabīr, 3:373; Tabari, Jāmi' al-Bayān, 3:2004; Tha'labi, Al-Jawāhir al-Hisān,1:363-64; Qurtubi, Mukhtār Tafsīr al-Qurtubī, 5:267; Wahidi, 'Ali ibn Ahmad, Asbāb al-Nuzūl (Beirut: 1988), 121-22; Zamakhshari, Al-Kashshāf, 1:537-38.

53. Ibn 'Adil, Al-Lubab, 6:441-51; Mawardi, Al-Nukat, 1:400-01; Razi, Tafsīr alKabīr, 3:370; Tabari, Jāmi ‘ al-Bayān, 3:2393; Tha'labi, Al-Jawāhir al-Hisān, 1:360-61; Qurtubi, Mukhtār Tafsir al-Qurtubi, 5:259-61.

54. Ibn Kathir, Tafsìr, 1:717; Razi, Tafsīr al-Kabīr, 6:426; Tabari, Jāmi ‘ al-Bayān 3:240-41; Qurtubi, Mukhtār Tafsīr al-Qurtubī, 5:268; Zamakhshari, AlKashshāf, 3:72.

55. Ibn 'Adil, Al-Lubab, 6:465; Razi, Tafsīr al-Kabīr, 3:370-73; Tabari, Jāmi ' alBayān, 3:2399-2400; Qurtubi, Mukhtār Tafsīr al-Qurtubī, 5:268-69; Zamakhshari, Al-Kashshāf, 1:538.

56. Ibn 'Adil, Al-Lubab, 6:441, 447-78; Ibn Kathir, Tafsīr, 1:709-12; Jassas, Ahkām, 2:213; Mawardi, Al-Nukat, 1:400; Razi, Tafsīr al-Kabīr, 3:356-58; Tabari, Jāmi ‘ 
al-Bayān, 3:2389-90; Tha'labi, Al-Jawāhir al-Hisān, 1:360-61; Qurtubi, Mukhtār Tafsìr al-Qurtubī, 5:259.

57. Ibn 'Adil, Al-Lubab, 6:447-48; Jassas, Aḥkām, 2:214; Tabari, Jāmi ' al-Bayān, 3:2389.

58. Ibn 'Adil, Al-Lubab, 6:441-42; Jassas, Ahkām, 2:211-12; Mawardi, Al-Nukat, 1:400; Razi, Tafsìr al-Kabīr, 3:358; Tabari, Jāmi ' al-Bayān, 3:2389; Qurtubi, Mukhtār Tafsīr al-Qurtubī, 5:259.

59. Ibn 'Adil, Al-Lubab, 6:447-48; Ibn Kathir, Tafsīr, 1:712; Jassas, Ahkām, 2:21112; Razi, Tafsīr al-Kabīr, 3:356-57; Qurtubi, Mukhtār Tafsīr al-Qurtubī, 5:260.

60. Ibn 'Adil, Al-Lubab, 6:441-51; Mawardi, Al-Nukat, 1:400-01; Razi, Tafsìr alKabīr, 3:370; Tabari, Jāmi ‘ al-Bayān, 3:2393; Tha'labi, Al-Jawāhir al-Hịisān, 1:360-61; Qurtubi, Mukhtār Tafsìr al-Qurtubī, 5:259-61.

61. Ibn 'Adil, Al-Lubab, 6:442-45; Ibn Kathir, Tafsīr, 1:711; Jassas, Ahkām, 2:21011; Mawardi, Al-Nukat, 1:400-01; Razi, Tafsìr al-Kabìr, 3:356-57; Tabari, Jāmi ‘ al-Bayān, 3:2390-93; Qurtubi, Mukhtār Tafsīr al-Qurtubī, 5:259-60.

62. Al-Busairi, Dictionary, 1; Ibn 'Adil, Al-Lubab, 6:445-48; Razi, Tafsīr al-Kabìr, 3:356-57; Ibn Taymiyah, Ahmad ibn Abd al-Halim, Tafsīr al-Kabīr, ed. and comp. Abd al-Rahman Umayrah (Beirut: Dar al-Kutub al-'Ilmiyah, 1988), 1:114-17. (Ibn Taymiyyah [d. 728/1328] does not have any specific tafsīr book; however a seven-volume work was compiled from his prolific written statements of Qur'anic exegesis entitled Tafsīr al-Kabìr.)

63. Ibn 'Adil, Al-Lubab, 15:550-51; Ibn Kathir, Tafsìr, 3:2254-55; Razi, Tafsìr alKabīr, 6:784-85; Tabari, Jāmi` al-Bayān, 8:6665-66; Qurtubi, Mukhtār Tafsīr al-Qurtubī, 14:187.

64. Ibn 'Adil, Al-Lubab, 15:550-51; Ibn Kathir, Tafsìr, 3:2253; Tabari, Jāmi ' alBayān, 8:6666; Qurtubi, Mukhtār Tafsīr al-Qurtubī, 14:187-88.

65. Qurtubi, Mukhtār Tafsīr al-Qurtubī, 14:187-88.

66. Ibn 'Adil, Al-Lubab, 15:550-51; Razi, Tafsìr al-Kabīr, 6:784-85; Qurtubi, Mukhtār Tafsīr al-Qurtubī, 14:186-88.

67. Ibn 'Adil, Al-Lubab, 15:550; Ibn Kathir, Tafsìr, 3:2253; Razi, Tafsīr al-Kabìr, 6:784; Tabari, Jāmi ‘ al-Bayān, 8:6665; Qurtubi, Mukhtār Tafsīr al-Qurtubī, $14: 186-87$.

68. Al-'Auwfiy, 'Aoud ibn Raja'a, Al-Wilayāt fì Nikāh, (Madinah: 2002) 1:65, AlBusairi, Dictionary, 107, 288, 294, 362; Al-Shinqiti, Muhammad al-Amin ibn Muhammad, Sharh Aād al-Mustghan 'i, transcripts of lectures by http://www. islamweibnnet, section 273; Qurtubi, Mukhtār Tafsir al-Qurtubi, 14:187-88.

69. Qurtubi, Mukhtār Tafsīr al-Qurtubī, 13:278, 14:187-88.

70. Ibn 'Adil, Al-Lubab, 15:550-51; Ibn Kathir, Tafsìr, 3:2255; Mawardi, AlNukat, 3:326; Razi, Tafsīr al-Kabīr, 6:784-85; Tabari, Jāmi ‘ al-Bayān, 8:666566; Qurtubi, Mukhtār Tafsīr al-Qurtubī, 14:186-88; Zamakhshari, Al-Kashshāf, $3: 262$.

71. Mawardi, Al-Nukat, 3:326; Tha'labi, Al-Jawāhir al-Hisān, 2:575; Zamakhshari, Al-Kashshāf, 3:262. 
72. Ibn 'Adil, Al-Lubab, 15:550-51; Ibn Kathir, Tafsīr, 3:2255; Mawardi, Al-Nukat, 3:326; Razi, Tafsīr al-Kabīr, 6:784-85; Tabari, Jāmi ‘ al-Bayān, 8:6665-66; Qurtubi, Mukhtār Tafsīr al-Qurtubī, 14:186-88; Zamakhshari, Al-Kashshāf, 3:262.

73. Abdel Haleem, Arabic English Dictionary, 481; Al-Busairi, Dictionary, 51; Ibn 'Adil, Al-Lubab, 7:373; Ibn Kathir, Tafsīr, 2:916-17; Mawardi, Al-Nukat, 1:470; Razi, Tafsīr al-Kabīr, 3:607-08; Tabari, Jāmi ' al-Bayān, 1:434, 4:2515; Tha'labi, Al-Jawāhir al-Hisān, 1:435; Qurtubi, Mukhtār Tafsīr al-Qurtubī, 6:211; Zamakhshari, Al-Kashshāf, 1:618.

74. Bukhari, Kitāb al-Hudūd, hadith no. 6841, 1179; Ibn al-Furs, Ahkām, 2:433-35; Ibn Kathir, Tafsìr, 2:904; Jassas, Aḥkàm, 2:439-40; Mawardi, Al-Nukat, 1:467; Razi, Tafsīr al-Kabìr, 2:610; Tabari, Jāmi ‘ al-Bayān, 4:2878-80; Tha'labi, AlJawāhir al-Hisān, 1:430-31.

75. Ibn al-Furs, Ahkām, 2:433-34; Ibn Kathir, Tafsīr, 2:906-07; Tabari, Jāmi ‘ alBayān, 4:2878-80; Tha'labi, Al-Jawāhir al-Hisān, 4:2879-80; Șahīh al-Bukhārī, 1179 , hadith no. 7841 .

76. Ibn al-Furs, Aḥām, 2:433-35; Ibn Kathir, Tafsīr, 3:905-07; Jassas, Aḥkām, 2:434; Razi, Tafsīr al-Kabīr, 3:600; Tabari, Jāmi ' al-Bayān, 4:2880; Qurtubi, Mukhtār Tafsīr al-Qurtubī, 6:187; Zamakhshari, Al-Kashshāf, 1:614.

77. Ibn 'Adil, Al-Lubab, 7:364; Ibn Kathir, Tafsīr, 2:915; Mawardi, Al-Nukat, 1:470; Razi, Tafsīr al-Kabìr, 3:607; Tabari, Jāmi' al-Bayān, 4:2909; Tha'labi, AlJawāhir al-Hisān, 1:434; Qurtubi, Mukhtār Tafsīr al-Qurtubī, 6:209.

78. Ibn Kathir, Tafsīr, 2:915; Tabari, Jāmi ‘ al-Bayān, 4:2909; Tha 'labi, Al-Jawāhir al-Hisān, 1:434; Qurtubi, Mukhtār Tafsīr al-Qurtubī, 6:209.

79. Zamakhshari, Al-Kashshāf, 1:614.

80. Ibn Kathir, Tafsīr, 2:917; Qurtubi, Mukhtār Tafsīr al-Qurtubī, 6:210-11; Tabari, Jāmi 'al-Bayān, 4:2915-16; Tha'labi, Al-Jawāhir al-Hisān, 1:434,

81. Ibn Kathir, Tafsīr, 2:917; Sahīh al-Bukhārī, hadith no. 3442, 3443, 580.

82. Abdel Haleem, Arabic English Dictionary, 232, 202; Wehr, Dictionary, 199, 171.

83. Ibn 'Adil, Al-Lubab, 9:342-44; Ibn Kathir, Tafsīr, 2:1160-62; Mawardi, AlNukat, 2:64-65; Razi, Tafsīr al-Kabìr, 4:442-43; Tabari, Jāmi ‘ al-Bayān, 5:3663; Ibn Taymiyyah, Tafsīr al-Kabīr, 7:275-76; Tha'labi, Al-Jawāhir alHisān, 1:580-81; Qurtubi, Mukhtār Tafsīr al-Qurtubī, 7:297; Zamakhshari, Al-Kashshäf, 2:122-23.

84. Ibn 'Adil, Al-Lubab, 9:343-44; Ibn Kathir, Tafsīr, 2:1160-63; Mawardi, AlNukat, 2:64-65; Razi, Tafsīr al-Kabīr, 4:443; Tabari, Jāmi` al-Bayān, 5:366365; Ibn Taymiyyah, Tafsīr al-Kabìr, 7:276-77; Tha'labi, Al-Jawāhir al-Hisā̄n, 1:581; Qurtubi, Mukhtār Tafsìr al-Qurtubī, 7:298-301; Zamakhshari, AlKashshāf, 2:122-23.

85. Abdel Haleem, The Qur'an: A New Translation, 105, see footnote; Ibn 'Adil, AlLubab, 9:344; Razi, Tafsīr al-Kabīr, 4:443; Tabari, Jāmi ‘ al-Bayān, 5:3663-64; Qurtubi, Mukhtār Tafsīr al-Qurtubī, 7:301; Zamakhshari, Al-Kashshāf, 2:123.

86. Mawardi, Al-Nukat, 2:63-65; Razi, Tafsīr al-Kabīr, 4:443; Tabari, Jāmi ‘ alBayān, 5:3663-65; Tha'labi, Al-Jawāhir al-Hisān, 1:580-81; Qurtubi, Mukhtār Tafsīr al-Qurtubī, 7:297-301; Zamakhshari, Al-Kashshāf, 2:122-23. 
87. Wehr, Dictionary 3, 1005.

88. Ibn 'Adil, Al-Lubab, 18:569; Ibn al-Furs, Ahkām, 3:540; Ibn Kathir, Tafsīr, 4:2807-09; Jassas, Ahkām, 3:429; Mawardi, Al-Nukat, 4:210; Razi, Tafsīr alKabīr, 17:286; Tabari, Jāmi ‘ al-Bayān, 10:7965; Tha'labi, Al-Jawāhir al-Hisā̄n, 3:315; Qurtubi, Mukhtār Tafsīr al-Qurtubī, 18:10-11; Zamakhshari, AlKashshāf, 4:82.

89. Ibn 'Adil, Al-Lubab, 18:581; Ibn al-Furs, Ahkām, 3:543-44; Ibn Kathir, Tafsīr, 4:2807-09; Mawardi, Al-Nukat, 4:211; Tha'labi, Al-Jawāhir al-Hisān, 3:316; Qurtubi, Mukhtār Tafsīr al-Qurtubī, 18:18-19; Zamakhshari, Al-Kashshāf, 4:82.

90. Abdel Haleem, Arabic English Dictionary, 195; Al-Busairi, Dictionary, 24-25; Zamakhshari, Al-Kashshāf, 1:511.

91. Ibn 'Adil, Al-Lubab, 6:232, 235; Ibn Kathir, Tafsīr, 1:632; Jassas, Ahkām, 2:10001; Razi, Tafsīr al-Kabīr, 3:242; Tabari, Jāmi ' al-Bayān, 3:2186; Ibn Taymiyyah, Tafsīr al-Kabīr, 7:293; Tha'labi, Al-Jawāhir al-Hisān, 1:334; Qurtubi, Mukhtār Tafsīr al-Qurtubī, 5:81-82; Zamakhshari, Al-Kashshāf, 1:511.

92. Ibn 'Adil, Al-Lubab, 6:232-34; Mawardi, Al-Nukat, 1:371; Razi, Tafsīr al-Kabīr, 3:242-43; Zamakhshari, Al-Kashshāf, 1:511.

93. Ibn 'Adil, Al-Lubab, 6:235; Razi, Tafsīr al-Kabīr, 3:242; Tabari, Jāmi' al-Bayān, 3:2186; Qurtubi, Mukhtār Tafsīr al-Qurtubī, 5:81; Zamakhshari, Al-Kashshāf, $1: 511$.

94. Abdel Haleem, Arabic English Dictionary, 267, 3:456.

95. Ibn 'Adil, Al-Lubab, 7:6; Ibn al-Furs, Ahkām, 1:278-79; Ibn Kathir, Tafsīr, 1:755-56; Jassas, Ahkām, 11:133-34; Mawardi, Al-Nukat, 1:422; Razi, Tafsīr alKabīr, 3:454-55; Tabari, Jāmi ‘ al-Bayān, 3:2521-22; Tha'labi, Al-Jawāhir alHisān, 1:383.

96. Ibn 'Adil, Al-Lubab, 7:6; Ibn al-Furs, Ahkām, 1:278-79; Ibn Kathir, Tafsīr, 1:755-56; Jassas, Ahkām, 11:133-34; Mawardi, Al-Nukat, 1:422; Razi, Tafsìr alKab̄̄r, 3:454-55; Tabari, Jāmi ‘ al-Bayān, 3:2524-27; Mawardi, Al-Nukat, 1:422.

97. Ibn 'Adil, Al-Lubab, 7:6; Ibn al-Furs, Ahkām, 1:278-79; Jassas, Ahkām, 11:13334; Mawardi, Al-Nukat, 1:422; Razi, Tafsīr al-Kabīr, 3:455-56; Tha'labi, AlJawāhir al-Hisān, 1:383; Zamakhshari, Al-Kashshāf, 1:561.

98. Razi, Tafsīr al-Kabīr, 3:456; Jassas, Ahkām, 11:133-34.

99. Ibn 'Adil, Al-Lubab, 7:7-8; Jassas, Ahkām, 11:133-34; Tabari, Jāmi ' al-Bayān, 3:2525; Tha'labi, Al-Jawāhir al-Hisān, 1:383.

100. Razi, Tafsīr al-Kabīr, 3:456-57; Tabari, Jāmi` al-Bayān, 3:2575; Tha'labi, AlJawāhir al-Hisān, 1:383-84.

101. Ibn al-Furs, Ahkām, 1:278-79.

102. Wehr, Dictionary, 195.

103. Ammar Fadzil, "An Analysis of Judgement of the Prophet Muhammad Based on the Occurrences of the Term Hukm in the Qur'an," Islamic Quarterly (1996): 142; Wehr, Dictionary, 455.

104. Abdel Haleem, Arabic English Dictionary, 763; Al-Busairi, Dictionary, 96.

105. Abdel Haleem, Arabic English Dictionary, 232; Al-Busairi, Dictionary, 16; Tabari, Jāmi ‘ al-Bayān, 9:7476-77; Zamakhshari, Al-Kashshāf, 3:543. 
106. Ibn 'Adil, Al-Lubab, 17:487-88; Ibn Kathir, Tafsīr, 4:2614; Mawardi, Al-Nukat, 4:59-60, 14:87; Tabari, Jāmi` al-Bayān, 9:7476-77; Tha'labi, Al-Jawāhir alHisān, 3:199-200; Qurtubi, Mukhtār Tafsīr al-Qurtubī, 16:267-68; Zamakhshari, Al-Kashshāf, 3:543.

107. Ibn Kathir, Tafsīr, 4:2614; Tabari, Jāmi ‘ al-Bayān, 9:7476-76; Tha'labi, AlJawāhir al-Hisān, 3:199.

108. Ibn Kathir, Tafsìr, 4:2612-16; Tabari, Jāmi` al-Bayān, 9:7476-77.

109. Ibn 'Adil, Al-Lubab, 17:487-88; Ibn Kathir, Tafsīr, 4:2614-16; Tabari, Jāmi ‘ alBayān 9:7476-77; Tha'labi, Al-Jawāhir al-Hisān, 3:199-200.

110. Ibn Kathir, Tafsīr, 4:2612-14; Tabari, Jāmi ‘ al-Bayān, 9:7476-77.

111. Ibn 'Adil, Al-Lubab, 17:487-88; Ibn Kathir, Tafsīr, 4:2614; Tabari, Jāmi' alBayān, 9:7476-77; Tha'labi, Al-Jawāhir al-Hisān, 3:199-200; Qurtubi, Mukhtār Tafsìr al-Qurtubī, 16:267-68.

112. Ibn Kathir, Tafsìr, 4:2612-14; Tabari, Jāmi ‘ al-Bayān, 9:7476-77.

113. Ibn 'Adil, Al-Lubab, 17:487; Ibn Kathir, Tafsīr, 4:2611; Mawardi, Al-Nukat, 4:59, 14:87; Tabari, Jāmi ‘ al-Bayān, 9:7476; Tha'labi, Al-Jawāhir al-Hisān, 3:199; Qurtubi, Mukhtār Tafsīr al-Qurtubī, 16:267; Zamakhshari, Al-Kashshāf, 3:543.

114. Ibn 'Adil, Al-Lubab, 17:487-88; Ibn Kathir, Tafsīr, 4:2614; Mawardi, Al-Nukat, 4:59-60, 14:87; Tabari, Jāmi ‘ al-Bayān, 7:476-77; Tha'labi, Al-Jawāhir alHisān, 3:199-200; Qurtubi, Mukhtār Tafsīr al-Qurtubī, 16267-68; Zamakhshari, Al-Kashshāf, 3:543.

115. Mawardi, Al-Nukat, 4:59, 14:87; Tha'labi, Al-Jawāhir al-Hisān, 3:199; Qurtubi, Mukhtār Tafsīr al-Qurtubī, 16:267; Zamakhshari, Al-Kashshāf, 3:543.

116. Ibn 'Adil, Al-Lubab, 17:487; Ibn Kathir, Tafsīr, 4:2615; Mawardi, Al-Nukat, 4:59, 14:87; Tabari, Jāmi ‘ al-Bayān, 9:7476-77; Tha'labi, Al-Jawāhir al-Hisā̄n, 3:199-200; Qurtubi, Mukhtār Tafsīr al-Qurtubī, 16:267-68; Zamakhshari, AlKashshāf, 3:543.

117. Abdel Haleem, Arabic English Dictionary, 232; Al-Busairi, Dictionary,16; Mawardi, Al-Nukat, 4:59; Tha'labi, Al-Jawāhir al-Hisān, 3:199; Qurtubi, Mukhtār Tafsīr al-Qurtubī, 16:267.

118. Ibn 'Adil, Al-Lubab, 17:487; Ibn Kathir, Tafsīr, 4:2611; Mawardi, Al-Nukat, 4:59-60, 14:87; Tabari, Jāmi' al-Bayān, 9:7476-77; Tha'labi, Al-Jawāhir alHisān, 3:199-200; Qurtubi, Mukhtār Tafsīr al-Qurtubī, 16:267-68; Zamakhshari, Al-Kashshāf, 3:543.

119. Bukhari, Muhammad ibn Isma'il, Șaḥ̄ḥ al-Bukhārī, Kitāb al-Tafsīr, hadith no. 4882. Hadiths narrated where Muhammad forbade Muslims to tattoo themselves are also found in Kitāb al-Libās, hadith no. 5931, 5939, 5943, 5948; Kitāb alTỉbb, hadith no. 5740; Kitāb al-Talāq, hadith no. 5347; Kitāb al-Bay 'ah, hadith no. 2238 . 